\title{
Pengaruh Kinerja Keuangan, Ukuran Perusahaan terhadap Struktur Modal
}

\author{
Chorina Elsa Fatika $^{1 *}$, Suhendro ${ }^{2}$, Anita Wijayanti ${ }^{3}$ \\ ${ }^{1,2,3}$ Universitas Islam Batik Surakarta, JL. KH. Agus Salim No. 10 , Jawa Tengah, Indonesia \\ *Correspondence email: fatikachorina@gmail.com, ${ }^{2}$ itax_solo@yahoo.com, ${ }^{3}$ dro_s@yahoo.com
}

\begin{abstract}
The purpose of this study is to examine and analyze the factors that influence the capital structure. The independent variables in this study are profitability, liquidity, asset structure, and company size. The population in this study are food and beverage companies listed on the Indonesia Stock Exchange for the period 2015-2018. The sample selection technique used in this study was purposive sampling and 10 company samples were obtained. The analytical method used in this study is multiple linear regression. The results of this study simultaneously show that profitability, liquidity, asset structure, and company size significantly influence the capital structure. The results of the research partially show that profitability, liquidity and firm size affect the capital structure, asset structure does not affect the capital structure.
\end{abstract}

Keywords: Financial Performance, Size, Capital Structure

\section{PENDAHULUAN}

Persaingan dalam dunia bisnis yang semakin luas membuat suatu perusahaan terutama perusahaan makanan dan minuman yang berusaha untuk meningkatkan kualitas keuangan perusahaan.. Salah satu cara yang dapat dilakukan untuk meningkatkan kualitas keuangan perusahaan dengan melalui peningkatan kemakmuran kepemilikan atau para pemegang saham. Keberadaan para pemegang saham sangat berpengaruh terhadap kelangsungan hidup dari perusahaan tersebut. Untuk itu perusahaan harus benar-benar pintar dalam mengelola keuangannya. Mengelola keuangan perusahaan perlu adanya perlakuan khusus pada modal yang dimiliki. Karena modal merupakan faktor penting dalam membangun dan menjamin kelangsungan perusahaan tersebut. Perusahaan membutuhkan modal dalam melakukan kegiatan usahanya yang digunakan untuk membiayai kegiatan operasional perusahaan sehingga dapat hidup dan terus berkembang dari tahun ke tahun. Modal suatu perusahaan terdiri dari dua sumber yaitu modal sendiri (equity) dan hutang $(d e b t)$, baik hutang jangka pendek maupun hutang jangka panjang. Hutang jangka pendek sering disebut hutang lancar, yaitu kewajiban yang harus dipenuhi dalam jangka waktu kurang dari satu tahun atau dalam jangka siklus bisnis perusahaan, sedangkan hutang jangka panjang adalah kewajiban yang harus dipenuhi dalam jangka waktu lebih dari satu tahun.

Menurut (Brigham \& Houston, Dasar-dasar Manajemen Keuangan, 2006), struktur modal adalah kombinasi antara utang, saham preferen dan saham ekuitas yang digunakan perusahaan untuk merencanakan mendapatkan modal. (Fahmi, 2014), menyatakan bahwa pemilihan komposisi struktur modal dapat dipengaruhi oleh banyak faktor. Dalam penelitian ini faktor yang mempengaruhi struktur modal meliputi profitabilitas, likuiditas, struktur aktiva, dan ukuran perusahaan. Analisis struktur modal merupakan hal yang penting. Karena, dapat mengevaluasi risiko jangka panjang dan prospek dari tingkat penghasilan yang didapatkan perusahaan selama menjalankan aktivitas. Berdasarkan latar belakang diatas perumusan masalah dalam penelitian ini adalah : (1) Apakah kinerja keuangan berpengaruh terhadap struktur modal ? (2) Apakah ukuran perusahaan berpengaruh terhadap struktur modal ? Dan tujuan penelitian ini adalah : (1) Untuk menguji dan menganalisa pengaruh kinerja keuangan terhadap strutur modal. (2) Untuk menguji dan menganalisa pengaruh ukuran perusahaan terhadap struktur modal. Dan Penelitian ini diharapkan bermanfaat untuk : (1) Manfaaat Teoretis ; Bagi peneliti : Penelitian ini diharapkan mampu memberikan pengetahuan bagi peneliti tentang pengaruh profitabilas, likuiditas, struktur aktiva, dan ukuran perusahaan terhadap struktur modal. Bagi penelitian selanjutnya Penelitian ini diharapkan mampu menjadi referensi bagi penelitian selanjutnya. (2) Manfaat Praktis ; Bagi perusahaan :Penelitian ini diharapkan mampu menambah pengetahuan bagi perusahaan tentang faktor-faktor yang mempengaruhi struktur modal sebuah perusahaan. Bagi calon investor :Penelitian ini diharapkan mampu menambah pengetahuan bagi calon investor tentang adanya pengaruh profitabilas, likuiditas, struktur aktiva, dan ukuran perusahaan terhadap struktur modal sebuah perusahaan.

\section{METODE}

Penelitian ini termasuk penelitian kuantitatif karena mengacu pada perhitungan dan analisis data berupa angkaangka. Instrumen Penelitian berupa dokumentasi laporan keuangan perusahaan makanan dan minuman yang terdaftar di BEI pada tahun 2015-2018. Populasi dalam penelitian ini adalah perusahaan perusahaan makanan dan minuman yang terdaftar di BEI pada tahun 2015-2018. Besaran sampel dalam penelitian ini adalah berjumlah 39 perusahaan. 
Pengambilan sampel dalam penelitian ini akan dilakukan dengan metode purposive sampling, dengan kriteria: (1) Perusahaan makanan dan minuman yang tidak mengalami kerugian selama periode tahun 2015-2018. (2) Perusahaan makanan dan minuman yang menggunakan mata uang rupiah dalam laporan keuangan. (3) Perusahaan makanan dan minuman yang memiliki data lengkap selama periode penelitian yaitu tahun 2015-2018. Teknik analisis data menggunakan regresi linier berganda, yang terdiri dari satu variabel dependen dan empat variabel independen. Berikut adalah model persamaan regresi linier berganda :

$\mathrm{Y}=\alpha+\beta 1 \mathrm{X} 1+\beta 2 \mathrm{X} 2+\beta 3 \mathrm{X} 3+\beta 4 \mathrm{X} 4+\mathrm{e}$

\section{HASIL}

Sampel dalam penelitian ini adalah 39 makanan dan minuman yang terdaftar di BEI periode 2015-2018. Pengambilan sampel dalam penelitian ini dengan metode purposive sampling.

Tabel 1

Penentuan Sample Penelitian

\begin{tabular}{llr}
\hline No & Kriteria Pemilihan Sampel & Jumlah \\
\hline 1 & Perusahaan manufaktur subsektor makanan dan minuman tahun periode 2015-2018. & 18 \\
2 & Perusahaan manufaktur subsektor makanan dan minuman yang mengalami kerugian selama periode 2015- & $(3)$ \\
3 & 2018. & $(5)$ \\
& Perusahaan konstruksi yang tidak memiliki data lengkap selama periode penelitian yaitu tahun 2015-2018. & 10 \\
& Jumlah Sampel & $\mathbf{4 0}$ \\
& Jumlah Observasi selama periode pengamatan (12x3tahun) & $(1)$ \\
& Jumlah Data Outlier & $\mathbf{3 9}$ \\
\hline
\end{tabular}

Tabel 2

Hasil Uji Normalitas

\begin{tabular}{llll}
\hline & Unstandardized Residual & Standar & Keterangan \\
\hline Asymp.Sig. (2-tailed) & 0,200 & $>0,05$ & Normal \\
\hline
\end{tabular}

Sumber : data olahan

Tabel 3

Hasil Uji Multikolinieritas

\begin{tabular}{llllll}
\hline \multicolumn{1}{c}{ Model } & Tolerance & Standar & VIF & Standar & Keterangan \\
\hline Profitabilitas & 0,832 & $>0,1$ & 1,201 & $<10$ & Tidak Terjadi Multikolinieritas \\
Likuiditas & 0,798 & $>0,1$ & 1,253 & $<10$ & Tidak Terjadi Multikolinieritas \\
Struktur Aktiva & 0,885 & $>0,1$ & 1,130 & $<10$ & Tidak Terjadi Multikolinieritas \\
Ukuran Perusahaan & 0,873 & $>0,1$ & 1,146 & $<10$ & Tidak Terjadi Multikolinieritas \\
\hline
\end{tabular}

Sumber : data olahan

Tabel 4

Hasil Uji Autokorelasi

\begin{tabular}{lllll}
\hline Model & $\mathrm{dU}<$ & $\mathrm{DW}$ & $<4-\mathrm{dU}$ & Keterangan \\
\hline 1 & $1,7215<$ & 1,745 & $<2,2785$ & Tidak terjadi autokorelasi \\
\hline
\end{tabular}

Sumber : data olahan

Tabel 5

Hasil Uji Heteroskedastisitas

\begin{tabular}{llll}
\hline Model & Sig. & Standar & Keterangan \\
\hline Profitabilitas & 0,727 & $>0,05$ & Tidak terjadi heteroskedastisitas \\
Likuiditas & 0,462 & $>0,05$ & Tidak terjadi heteroskedastisitas \\
Struktur Aktiva & 0,411 & $>0,05$ & Tidak terjadi heteroskedastisitas \\
Ukuran Perusahaan & 0,965 & $>0,05$ & Tidak terjadi heteroskedastisitas \\
\hline
\end{tabular}

Sumber : data olahan 
Tabel 6

Hasil Uji Analisis Regresi Linear Berganda

\begin{tabular}{|c|c|c|c|c|c|}
\hline \multirow{2}{*}{ Variabel } & \multicolumn{2}{|c|}{ Unstandardized Coefficients } & Standardized Coefficients & \multirow[b]{2}{*}{$\mathrm{t}$} & \multirow[b]{2}{*}{ Sig. } \\
\hline & $\mathrm{B}$ & Std. Error & Beta & & \\
\hline (Constant) & 3,634 & 0,948 & & 3,832 & 0,001 \\
\hline Profitabilitas & 1,431 & 0,620 & 0,248 & 2,309 & 0,027 \\
\hline Likuiditas & $-0,205$ & 0,025 & $-0,886$ & $-8,077$ & 0,000 \\
\hline Struktur Aktiva & 0,082 & 0,080 & $-0,107$ & $-1,029$ & 0,311 \\
\hline Ukuran Perusahaan & $-0,081$ & 0,032 & $-0,270$ & $-2,577$ & 0,014 \\
\hline
\end{tabular}

Sumber : data olahan

Tabel 7

Hasil Kelayakan Model (Uji F)

\begin{tabular}{llllll}
\hline Model & $\mathrm{F}_{\text {hitung }}$ & $\mathrm{F}_{\text {tabel }}$ & Sig. & Standar & Keterangan \\
\hline 1 Regression & 17,514 & $>2,65$ & 0,000 & 0,05 & Model layak \\
\hline
\end{tabular}

Sumber : data olahan

Tabel 8

Hasil Uji Hipotesis

\begin{tabular}{llllll}
\hline Hipotesis & $\mathrm{t}_{\text {hitung }}$ & $\mathrm{t}_{\text {tabel }}$ & Sig & Standar & Keterangan \\
\hline H1 (Profitabilitas) & 2,309 & $>1,697$ & 0,027 & $<0,05$ & Diterima \\
H2 (Likuiditas) & $-8,077$ & $<-1,697$ & 0,000 & $<0,05$ & Diterima \\
H3 (Struktur Aktiva) & $-1,029$ & $>-1,697$ & 0,311 & $<0,05$ & Ditolak \\
H4 (Ukuran Perusahaan) & $-2,577$ & $<-1,697$ & 0,014 & $<0,05$ & Diterima \\
\hline
\end{tabular}

Sumber : data olahan

Tabel 9

Hasil Uji Koefisien Determinan

\begin{tabular}{lll}
\hline Model & Adjusted R Square & Keterangan \\
\hline 1 & $63,5 \%$ & variabel profitabilitas, likuiditas, struktur aktiva, dan ukuran perusahaan, secara simultan \\
& & berpengaruh terhadap variabel struktur modal sebesar $63,5 \%$
\end{tabular}

Sumber : data olahan

Variabel profitabilitas mempunyai nilai sig. sebesar 0,027 yang berarti lebih kecil dari nilai signifikansi $\alpha$ yaitu 0,05. Hal tersebut berarti profitabilitas berpengaruh secara signifikan terhadap struktur modal. Hasil ini sesuai dengan pernyataan hipotesis pertama yang menyatakan profitabilitas berpengaruh terhadap struktur modal sehingga $\mathrm{H}_{1}$ diterima. Hasil ini juga mendukung penelitian yang dilakukan oleh (Eunike Gita Tangkulung, Sri Murni, Victoria N. Untu, 2019) yang menyatakan bahwa Profitabilitas berpengaruh terhadap struktur modal. Perusahaan menggunakan utang yang relatif lebih rendah jika perusahaan mempunyai tingkat pengembalian yang tinggi. Variabel likuiditas mempunyai nilai sig, sebesar 0,000 yang lebih kecil dari nilai signifikansi $\alpha$ yaitu 0,05 . Hal tersebut berarti likuiditas berpengaruh secara signifikan terhadap struktur modal atau dengan kata lain $\mathrm{H}_{2}$ diterima. Hasil ini juga mendukung penelitian yang dilakukan oleh (Stenyverens J.D Lasut, Paulina Van Rate, Michael Ch. Raintung, 2018) yang menyatakan bahwa Likuiditas berpengaruh terhadap struktur modal. Tingkat likuiditas dalam penelitian ini besar sehingga perusahaan mampu membayar hutang jangka pendeknya. Variabel struktur aktiva mempunyai nilai sig, sebesar 0,311 yang lebih besar dari nilai signifikansi $\alpha$ yaitu 0,05 . Hal tersebut berarti struktur aktiva tidak berpengaruh secara signifikan terhadap struktur modal atau dengan kata lain $\mathrm{H}_{3}$ ditolak. Hasil ini tidak sesuai penelitian yang dilakukan oleh (Muhammad Jalil, 2018) yang menyatakan struktur aktiva berpengaruh terhadap struktur modal.

Variabel ukran perusahaan mempunyai nilai sig, sebesar 0,014 yang lebih besar dari nilai signifikansi $\alpha$ yaitu 0,05. Hal tersebut berarti ukran perusahaan berpengaruh terhadap struktur modal, sehingga $\mathrm{H}_{4}$ diterima. Hasil ini juga mendukung penelitian yang dilakukan oleh (Stenyverens J.D Lasut, Paulina Van Rate, Michael Ch. Raintung, 2018) yang menyatakan bahwa ukuran perusahaan berpengaruh terhadap struktur modal. besarnya hutang jangka panjang berpengaruh penentuan struktur modal perusahaan. Hasil uji koefisien determinasi diperoleh nilai sebesar 0,635 . Hal ini menunjukkan profitabilitas, likuiditas, struktur aktiva, danukuran perusahaan sebesar 63,5\%, sedangkan sisanya sebesar $36,5 \%$ dipengaruhi oleh faktor-faktor lain yang tidak diteliti dalam penelitian ini.

\section{SIMPULAN}

Penelitian ini bertujuan untuk mengetahui pengaruh profitabilitas, likuiditas, struktur aktiva, dan ukuran perusahaan terhadap struktur modal. Populasi dalam penelitian ini adalah perushaan makanan dan minuman tahun 20152018. Hasil pengujian menggunakan teknik analisis regresi linier berganda menunjukkan bahwa: (1) Profitabilitas berpengaruh secara signifikan terhadap struktur modal. (2) Likuiditas berpengaruh secara signifikan terhadap struktur 
modal. (3) Struktur aktiva tidak berpengaruh secara signifikan terhadap struktur modal. (4) Ukuran perusahaan berpengaruh terhadap struktur modal. Penelitian ini memiliki keterbatasan yaitu : (1) penelitian ini hanya memiliki pengaruh sebesar 63,5\% sedangkan 36,5\% dijelaskan di variabel lain. (2) variabel yang digu nakan di penelitian ini hanya dibatasi 4 variabel yaitu : profitabilitas, likuiditas, struktur aktiva, dan ukuran perusahaan. (3) perusahaan yang digunakan masih sedikit.

\section{DAFTAR PUSTAKA}

AAriyanto, T. (2002). Pengaruh Struktur Kepemilikan Terhadap Struktur Modal Perusahaan. Jurnal Manajemen Indonesia, 1(1), 64-71.

Ariyanto, T. (64-71). Pengaruh Struktur Kepemilikan Terhadap Struktur Modal Perusahaan. Jurnal Manajemen Indonesia, $1(1)$.

Brigham, \& Ehrhardt. (2005). Financial Management : Theory And Practice, Eleventh Edition (Eleventh Edition ed.). United States Of America: Thomson South.

Brigham, E. F. (2011). ESSENTIAL OF FINANCIAL MANAGEMENT SINGAPORE CENGAGE LEARNING, Dasar-dasar Manajemen Keuangan. Manajemen Keuangan.

Brigham, E., \& Houston, J. (2009). Dasar-dasar Manajemen Keuangan (10 Edition ed.). Jakarta: Salemba Empat.

Brigham, E., \& Joel, F. (2006). Dasar-Dasar Manajemen Keuangan (Edisi 10 ed.). Jakarta: Salemba Empat.

Dewi, N. K., \& I.B, B. (2014). Pengaruh Likuiditas, Profitabilitas, Tangibility Assets, Ukuran Perusahaan dan Pajak Terjadap Struktur Modal. E-Jurnal Manajemen Universitas Udayana, 3(10), 3017-3033.

Ervina. (2011). Faktor-faktor yang Mempengaruhi Struktur Modal pada Perusahaan Farmasi dan Kimia yang Terdaftar di Bursa Efek Indonesia Periode 2007-2011. Jurnal Jurusan Akuntansi.

Eunike Gita Tangkulung, S. M. (2019). PENGARUH ASSET SIZE DAN PROFITABILITAS TERHADAP STRUKTUR MODAL PADA PERUSAHAAN REAL ESTATE DAN PROPERTY.

Ghozali, I. (2011). Aplikasi Analisis Multivariate dengan Program SPSS. Semarang: Badan Penerbit Universitas Diponegoro.

Gill, A., \& Shah, C. (2012). Determinant of Corporate Cash Holdings: Evidence From Canada. International Journal of Economics and Finance Vol. 4, 70-79.

Harmono. (2015). Manajemen Keuangan berbasis balanced scorecard.

Houston, B. (2011). Dasar dasar Manajemen Keuangan Buku 2 (11 ed). Jakarta: Salemba Empat.

Kanita, G. G. (2014). Pengaruh Struktur Aktiva dan Profitabilitas terhadap Struktur Modal Perusahaan Makanan dan Minuman. 127-135.

Kasmir. (2011). Analisis Laporan Keuangan. Cetakan Keempat. Jakarta: Rajawali Pers.

Kurniawan, M., \& Nuryanah, S. (2017). The Effect of Corporate Tax Avoidance on the Level of Cash Holdings : Evidence from Indonesian Public Listed Companies. Australasian Accounting, Bussiness, and Finance Journal, Vol 11.

Maryanti, E. (2016). Analisis Profitabilitas, Pertumbuhan Perusahaan, Pertumbuhan Penjualan Dan Struktur Aktiva Terhadap Struktur Modal Pada Perusahaan Sektor Industri Barang Konsumsi Yang Terdaftar Di Bursa Efek Indonesia. Riset Akuntansi Dan Keuangan Indonesia, I(2), 156-167.

Riyanto, B. (2001). Yogyakarta: BPFE.

Riyanto, B. (2010). Dasar-Dasar Pembelanjaan Perusahaan (Vol. IV). Yogyakarta: BPFE.

Riyanto, B. (2011). Dasar-dasar Pembelanjaan Perusahaan (Edisi Keempat ed.). Yogyakarta: BPFE.

Saidi. (2004). Faktor-faktor yang Mempengaruhi Struktur Modal pada Perusahaan Manufaktur Go Public di BEI. Jurnal Bisnis dan Ekonomi, 1 (11), 44-58.

Saidi. (2004). Faktor-faktor yang Mempengaruhi Struktur Modal pada Perusahaan Manufaktur Go Public di BEJ. Jurnal Bisnis dan Ekonomi, 1(11), 44-58.

Sari, A. (2016). Pengaruh Profitabilitas, Likuiditas, Pertumbuhan Aset Dan Ukuran Perusahaan Terhadap Struktur Modal. Jurnal Ilmu \& Riset Manajemen, 5(4).

Sartono. (2010). Manajemen Keuangan. Yogyakarta : BPFE.

Sartono, J. (2006). Metode Penelitian Kuantitatif dan Kualitatif. Yogyakarta: Graha Ilmu.

Sartono, R. (2001). Manajemen Keuangan Teori dan Aplikasi. Yogyakarta: BPFE.

Stenyverens J.D Lasut, P. V. (2018). pengaruh ukuran perusahaan , PROFITABILITAS, DAN LIKUIDITAS TERHADAP STRUKTUR MODAL PADA PERUSAHAAN OTOMOTIF YANG TERDAFTAR DI BURSA EFEK INDONESIA PERIODE 2012-2015. akuntansi.

Weston, J., \& T.E, C. (2008). Manajemen Keuangan. Jakarta: Binarupa Aksara.

Widiastuti N.A, R. A., \& Oemar. (2016). Pengaruh Leverage, Ukuran Perusahaan, Pertumbuhan Perusahaan, Rasio Likuiditas Dan Rasio Aktivitas Terhadap Profitabilitas (Studi Pada Sektor Keuangan dan Perbankan di BEI Tahun 2010-2014). Journal Of Accounting, 2(2). 